\title{
On the question of some tendencies in the unification of national and international jurisdiction of Internet disputes
}

\author{
Valeriya Dmitrievna Melnik* \\ Ural State Law University, 21, Komsomolskaya St., Yekaterinburg, 620137, Russia
}

\begin{abstract}
The author analyzes the development of foreign legislative and law enforcement approaches to resolving the issue of Internet disputes jurisdiction. It is concluded that today the development of national and international legal regulation of issues Internet disputes jurisdiction occurs in two directions: firstly, the reception of national jurisdiction legal approaches in international legal acts; secondly, the implementation of international legal acts approaches into national legislation. The author draws attention to the fact that, in the absence of a universe international treaty regulating the issues of Internet disputes international jurisdiction, a detailed development of national law rules, regardless of the particular jurisdiction, taking into account the specifics of Internet relations and Internet disputes cannot solve the problem of jurisdiction conflict in resolving this category of disputes.
\end{abstract}

\section{Introduction}

The volume growth of online legal relations naturally leads to the growth of disputes arising from them. At the same time, the courts resolving such disputes, regardless of which state they extend their powers to, often face questions related to the interstate nature of the Internet and the technical specifics of its functioning. The development of rules for determining the competent authority for considering Internet disputes is supposed to be one of these issues.

The complication of resolving this issue of determining the competent authority for the consideration of Internet disputes is based on a number of features of the Internet functioning and, consequently, Internet legal relations, including:

1) the use of special technical means by the subjects of the legal relations [1];

2) "anonymization" of subjects of the legal relations, manifested in the possibility of participation in the legal relations without specifying identification features [2];

3 ) the remoteness (even on an interstate scale) of the subjects from each other [3];

4) transboundariness as a natural consequence of the presence of legal entities and third parties in different jurisdictions [4].

Before turning to a direct analytical presentation of the article matter, it is considered possible to note that for the purposes of this article, Internet disputes are understood as the disputes in which the fact of using the Internet affects the determination of the competent authority for the consideration of the dispute, the establishment of the parties to a case, the subject of evidence in the case and permissible means of proof. At the same time, the definition is not unified, since other definitions of Internet disputes can be found in the scientific literature [5].

The complication of legal relations arising on the Internet by a foreign element determines the intention of various countries to legally qualify the actions of their participants. Considering Internet relations specifics and the enlargement of the Internet relations segment in the social space, both at the level of individual states and at the international level, general and casual (i.e. relevant to certain types of Internet disputes (such as domain disputes, etc.)) rules for determining Internet disputes jurisdiction are being developed.

\section{Determining the jurisdiction of Internet disputes: the USA experience}

The United States is the center of concentration of the largest domain zones (.com; org; .net). Due to it American law has become one of the first to establish special rules for determining jurisdiction of Internet disputes. The development of new rules was concerned with the need of division of the competence of the courts from different states.

In determining jurisdiction in Internet disputes, American courts are guided by both traditional rules and criteria customized to the online space: personal jurisdiction, a "sliding scale" test and purposeful subordination.

The personal jurisdiction rule is a general jurisdictional rule assumes that a state court has jurisdiction to consider a dispute against a person if he physically presents on its territory [6].

One of the first American cases in which judges paid attention to the extraterritorial nature of the Internet 
when determing the limits of personal jurisdiction was Inset Systems, Inc. (Inset) v. Instruction Set, Inc. (INI), 1996. In that case the extraterritorial nature of the Internet was concerned with the possibility of bringing information to the attention of Network users in an unlimited volume and in an indefinite geography.

Considering the dispute, the court came to the conclusion that it is necessary to apply a long-arm statute, which implies the extension of the right beyond the territorial jurisdiction of the court, to advertising posted on the Internet [7].

Further development of the personal jurisdiction rule in relation to Internet disputes is associated with the use of the 'minimum contacts' test in the cases of International Shoe Co v. Washington, 1945 and Maritz, Inc. v. Cybergold, Inc., 1996 [8]. In essence, this is a five-step approach, on the basis of which it is determined that it is possible to extend the jurisdiction of the court of the state in which the dispute is being considered to a non-resident defendant.

"Minimum contacts" refer to the actions of the defendant that have such a level of contact with the forum state that makes him to reasonably expect a claim to be filed in this state. The "minimum contacts" test is aimed at determining a number of circumstances: 1) the nature and quality of the contacts with the forum state; 2) the quantity of the contacts; 3 ) the relation of the cause of action to those contacts; 4) the interest of the forum state in extending its jurisdiction to its residents; 5) the interest of the parties to the dispute [8].

The first three criteria are the main ones, while the last two are of a secondary nature.

Another traditional test for determining personal jurisdiction, in addition to "minimum contacts", is "Calder test" (Calder v. Jones, 1984). According to this rule, transformed under the online world, the personal jurisdiction of the court can be extended to a nonresident, if he 1) committed intentional actions, 2) directly aimed at the forum state, 3) with the understanding that the main damage of the actions will be caused in the forum state [9].

The first special jurisdictional rule for Internet disputes was the "sliding scale" rule, or "Zippo test", in the case of Zippo Manufacturing Co. v. Zippo Dot Com, Inc., 1997. It reflects the influence of a website interactivity degree on the possibility of providing personal jurisdiction.

When resolving this dispute, the court used an innovative approach. It proposed to determine the extension of the court's jurisdiction to the website by a three-step scale, each step of which is determined by the nature and quality of business activities carried out via the Internet. The court presented the next structure of the scale:

- at the one end of the scale there are cases in which the defendant is using a website for doing business with a high degree of evidence, and it is so-called "active website". For example, if the defendant makes deals with residents of another state and they involve the exchange of computer files, then personal jurisdiction is appropriate.
- at the opposite end there are cases where the defendant only posts on the Internet some information available to residents of another state. This type of website is supposed to be "passive". Even if the defendant acts more through a passive website than with a simple posting of information, is does not form a personal jurisdiction.

- at the center of the scale there are situations with the defendant having an interactive website through which users can interact with the host computer. In such cases, the resolution of the jurisdiction issue depends on the degree of interactivity and commercialization of the information exchange via the website [10].

The development of the scale forced American courts to use the methodology of classifying websites into active and passive. If the passivity of the defendant's website is established, personal jurisdiction over the is abscent (ex. Bensusan Restaurant Corp. v. King, 1996, Cybersell, Inc. v. Cybersell, Inc.)

Despite the breadth of applications, American legal society criticizes Zippo test. It has become a kind of "trigger" for the development of additional criteria for personal jurisdiction - purpose, or purposeful activities (Toys «R» Us [11], Inc. v. Step Two, Kindig v. Creative Controls [12]).

Further development of the jurisdictional rules in the United States occurred in light of the eBay promotion.

The question of whether the forum state jurisdiction can be established in cases where a non-resident defendant uses an intermediary website (eBay) available to residents of the forum state was firstly raised in the case of Boschetto v. Hansing [13]. In this case, the court, rejecting the claim due to the lack of personal jurisdiction, pointed out that the fact of selling only one car through the eBay website in the absence of any other actions cannot entail the extension of the personal jurisdiction of the forum state to a non-resident person. Thus in the case of Attaway v. Omega [14] court established personal jurisdiction not only through the "minimum contacts" test, but also on the basis of the defendant's actions in the form of appearing (even through an agent) in the forum state to receive goods purchased via the Internet.

Despite the obvious variety of American approaches developed for determining jurisdiction in Internet disputes, courts rarely use only one criterion when considering particular Imternet disputes cases. On the contrary, in judicial acts, there is often a consistent application of several criteria - from the 'Zippo test' and the 'Calder test' up to relatively innovative methods that arise in the light of E-commerce development. At the same time, the practice of US courts cannot demonstrate the uniformity. For example, some courts adopt a "sliding scale" as the only mechanism for checking the existence of personal jurisdiction but others consider the inadmissibility of the approach. It goes without saying that this thesis can be easily justified by the need for the common law courts to be guided more by actual circumstances than by the desire to "attract" the circumstances of new disputes to successfully developed legal positions. 
However, it still seems that the formation of judicial practice uniformity cannot and should not be the prerogative of only the courts of the civil legal system, since the mentioned uniformity is a well-known mechanism for ensuring stability and predictability of business. The latter, in the conditions of almost uncontrolled development of the online world, can be guaranteed at least through traditional state and interstate institutions in the form of jurisdictional rules. Both corporations and persons who act in the Internet space should understand which of their actions can affect the forum state, and which can not. Such awareness will either minimize the risks of initiating disputes in a foreign jurisdiction, or exclude a potential "surprise" in the form of a lawsuit in a foreign country. Despite this, it would be absolutely wrong to deny the substantial development of American judicial practice in the jurisdictional aspect of the issue of Internet dispute resolving and exclude the possibility of accepting some of the mechanisms developed by it by Russian procedural law.

\section{Determining the jurisdiction of Internet disputes: the EU experience}

Nowadays there are some international treaties regulating jurisdictional issues are in force in the European Union.

For example, in the Brussels I Regulation on jurisdiction and the recognition and enforcement of judgments in civil and commercial matters (as amended by EU Directive No. 1215/2012) [15] the jurisdictional rules are classified as general and special.

Under the general rule, persons domiciled in a member state shall, whatever their nationality, be sued in the courts of that member state. Persons domiciled in a member state may be sued in the courts of another member state only by virtue of the rules set out in the Regulation. Special rules are established in Art. 7.

Thus, a person may act as a defendant in a court of another EU member state, in particular, in the following cases:

1) in matters relating to a contract, in the courts for the

place of performance of the obligation in question;

2) in matters relating to tort, delict or quasi-delict, in the courts for the place where the harmful event occurred or may occur;

3 ) if he is one of a number of defendants, in the courts for the place where anyone of them is domiciled, provided the claims are so closely connected that it is expedient to hear and determine them together to avoid the risk of irreconcilable judgments resulting from separate proceedings, etc.;

The jurisdiction over disputes relating to insurance, as well as those arising from consumer contracts, is also determined in a special way.

Regarding the consumer disputes, the Regulation establishes that the consumer has the right to sue both at the state of his domicile and at the state of the defendant's domicile. This includes if the contract was concluded with a party engaged in commercial or other professional activities in the consumer's domicile or otherwise directs his activities to the consumer's domicile or to several member states, including the consumer's domicile, and the contract falls within the scope of this activity.

Brussels I Regulation, which entered into force on January 2015, is now also used to determine jurisdiction for disputes with non-EU residents.

Despite the fact that the Regulation does not contain special rules on the issues of jurisdiction in relation to Internet disputes, the general rules that exist in it are quite correlated with the issues arising during the resolution of jurisdictional conflicts and allow them to be prevented.

The EU's jurisdictional rules are also contained, in particular, in the Lugano Convention of 16 September 1988 on the Jurisdiction and Enforcement of Judgments in Civil and Commercial Matters [16] and Regulation (EU) 2017/1001 of the European Parliament and of the Council of 14 June 2017 on the European Union trade mark [17].

The EUTMR establishes autonomous rules of international jurisdiction over the disputes on infringement of an EU trademark, directly excluding the application of both the jurisdictional rules of the Brussels I Regulation and the national rules of the EU member States applicable to foreigners when considering disputes on infringement of national trademarks.

The violation of the EUTMR disputes are subject to consideration in the specialized courts for EU trademarks existing in the each of member states. Thus, the place of consideration of the dispute always exists within the EU. The main question is in which state the dispute should be resolved.

Despite the European law is primarily considered to be a civil law, the development of special jurisdictional rules applicable to Internet disputes does not occur through the adoption of additional international acts, but mainly through the development of legal approaches by the European Court of Justice.

The European Court pays special attention to the issues of applying the test factor of lex loci delicti, which allows suing at the place of actual or potential occurrence of harm.

For example, with regard to copyright, there are currently two most common ways of determination the place of commission of a tort in the Internet:

1) intention to target - the country of whose people of the site is addressed to;

2) accessibility online - the country where the site with the content is available;

The first approach is reflected in the decision of October 18, 2012 in the case of Sportradar (C-173/11) [18] - the jurisdiction is held by the court of the country whose users the content of the website is addressed to.

Concluding that focusing on the targeting of content does not always meet the general rule of fairness in dispute resolution, the European Court rejected it in favor of the actual availability of content in the case of Pinckney (C-170/12) [19]. With this approach, the court of the state in which the content posted on the website is 
available, which, according to the plaintiff, violates his copyright, will have the competence to consider a dispute on the recovery of damages caused by copyright infringement.

The European Court paid special attention to the issues of jurisdiction in disputes related to the violation of trademark rights on the Internet.

The territoriality principle applies to the legal protection of trademarks. It means that the exclusive right to a trademark is valid within the state that has granted legal protection [20]. Consequently, a violation of the exclusive right to a trademark can take place only if it is committed in this state.

Thus, in the Wintersteiger case [21], the EU court pointed out that the concept of causing harm for the purposes of establishing jurisdiction may not coincide with the concept of causing harm in accordance with substantive law. The first is determined in accordance with the Brussels I Regulation. The EU Court of Justice confirmed that in the context of online trademark violations, the concept of "places where a tort has occurred or may occur" in Article 7 (2) of the Regulation also covers both the place where the damage was caused and the place of the event that caused the damage. Based on this, a claim for violation of the right to a national trademark can be brought in the courts of the member state in which it is registered, since protection in this case is limited to the territory of that State, and this State will be the place where the damage was allegedly caused.

The question of whether the defendant's actions constitute a violation should be assessed by the court of the state of protection of the mark in the light of the applicable substantive law.

In addition, the EU Court noted that the territorial restriction of the protection of a national mark does not exclude the international jurisdiction of courts of other states, in addition to where the trademark is registered. This legal position was expressed by the EU Court in the sense that in disputes related to trademark infringement, the place of the event that caused the damage is the place of activation of the ad display process. Since this place, associated with the location of the server of the search engine operator, is often uncertain, in these disputes, the location of the advertiser must be considered the place of commission of the offense [21].

\section{Unification of jurisdictional approaches to the consideration of Internet disputes: the essence and prospects}

After analyzing the development of national and international legal regulation of issues of Internet disputes jurisdiction, it is possible to distinguish two directions.

The first direction consists in the reception of national jurisdiction legal approaches in international legal acts.

The USA is a kind of driving force in matters of regulating Internet relations and Internet disputes related to them. Due to the concentration of the largest commercial entities on the US territory, which laid the foundations for the E-commerce development, and specific federal relations, it was necessary for the USA to develop approaches that allow resolving jurisdictional issues between the states. The criterion of purposeful subordination, the 'Zippo test' and the 'Calder test' were developed through American law enforcement practice. Subsequently, these approaches were gradually reflected in the practice of the EU Court of Justice.

Although EU law, when determining jurisdiction, adheres to the criterion of the place of commission of a tort or the occurrence of damage, and in American law, on the contrary, the most common criterion is the purpose of the defendant's activity, sometimes the opposite is also found in practice. In addition, the criterion of the place of commission of a tort or the occurrence of damage in Internet disputes is comparable in its content to the 'Calder test'.

Thus, the analysis of the previously cited Sportradar case $(\boldsymbol{C}-173 / 11)$ shows that the European law-enforcer is trying to exercise the powers that the US courts have to adjust the jurisdictional provisions enshrined in the Brussels I Regulation, "expanding" the criterion of the place of damage by the criterion of site availability, that is, the purposeful subordination.

The second direction consists in the implementation of international legal acts approaches into national legislation

For example, in Article 247 of the Arbitration Procedure Code of the Russian Federation, the criterion of causing harm or the place of occurrence of damage (paragraph 4 of Part 1), and the criterion of purposeful impact on the territory of the Russian Federation (paragraph 9 of Part 1), and the principle of close connection (paragraph 10 of Part 1) are fixed. Similar criteria are contained in Part 3 of Article 402 of the Civil Procedural Code of the Russian Federation.

Without the purpose to analyze mainly and exclusively the Russian procedural rules for determining the competence of Russian courts in relation to Internet disputes in this article, it should be briefly noted that to some extent they really cope with the resolution of such issues.

Nevertheless, the paradox of the jurisdictional rules, which are best known to the legal community, is that they are aimed at establishing the connection of an Internet dispute with the territory of a state, i.e. they are territorial in nature. In turn, one of the key features of the Internet is its extraterritorial nature, due to which it is not always possible to establish the territorial limits of Internet influence [22].

The degree of influence actually exerted on users via the Internet cannot be quantified. It is not limited by any territorial or personal limits. It is not even limited by chronological limits.

Information that gets online on one continent becomes available almost immediately on another continent, no matter what audience it is aimed at. Here Henry Adams' statement seems appropriate: "The difference is slight, to the influence of an author, whether he is read by five hundred readers, or by five 
hundred thousand; if he can select the five hundred, he reaches the five hundred thousand" [23].

Therefore, it is possible to create highly developed national law rules regulating the Internet disputes jurisdictional issues as much as necessary, but they will act exactly as long as they do not "collide" with the equally perfectly constructed law rules of a foreign legal system. Usually and truly predictably, state courts that implement one of the important components of the state sovereignty, resolving jurisdictional issues, proceed from the intention to establish their competence to resolve an Internet dispute in various ways, while excluding the possibility of establishing jurisdiction over this issue of another state. Thus, the conflict of jurisdictions in the framework of Internet disputes resolving becomes inevitable.

The existing international legal regulation is clearly globally insufficient to prevent this conflict: there is no global international treaty regulating the issues of international jurisdiction of Internet disputes.

The adoption of European regulations, including those of a special nature, is an important step towards the unification of international and national jurisdiction in the European space. However, its effect is limited to the EU.

\section{Conclusion}

It goes without saying that, given the current political situation, the possibility of concluding an international agreement on cooperation between countries in resolving Internet disputes is significantly limited. At the same time, a departure from the actually widespread paradigm of mediating one thing by another (which dominates something - a question that goes beyond both the research topic and the law) and cooperation in the perception of the best practices for resolving Internet disputes jurisdictional issues that are common in various countries would allow creating a universal international document. That significantly reduces jurisdictional conflicts when considering and resolving Internet disputes.

\section{References}

1. N.N. Teleshina, Virtual space as a new legal construction: to the formulation of the problem, Legal technique, 7 (part 2), 745 (2013)

2. M.F. Radaykin, Briefly about the problem of anonymity on the Internet, Gaps in Russian legislation, 2, 26 (2013)

3. L.V. Terentyeva, Network space and state borders: issues of jurisdiction on the Internet, Law. Journal of the Higher School of Economics, 1, 4 (2010)

4. L.V. Terentyeva, Conflict of laws regulation of copyright relations in the conditions of Internet development (on the example of Russia, the USA and Japan), Law. Journal of the Higher School of Economics, 3, 172 (2013)

5. A.V. Neznamov, Features of competence in the consideration of Internet disputes (Infotropik Media, Moscow, 2011) The series "Civil and Arbitration process: new names \& new ideas". p. 28.

6. E. Leanovich, Problems of Legal Regulation of the Internet Relations with a Foreign Element, Belarusian Journal of International Law and International Relations, 4, 39 (2000)

7. Inset Systems, Inc. v. Instruction Set, Inc., 937 F. Supp. 161 (D. Conn. 1996).

8. Maritz, Inc. v. Cybergold, Inc., 947 F. Supp. 1328 (E.D. Mo. 1996).

9. Dudnikov and Meadors v. Chalk \& Vermilion, Inc. and Sevenarts, Ltd., 514 F.3d 1063 (10th Cir. 2008).

10. Zippo Manufacturing Co. v. Zippo Dot Com, Inc., 952 F.Supp. 1119, 1121 (W.D. Pa. 1997).

11. Toys "R" Us, Inc. Geoffrey, Inc. v. Step Two, S.A. Imaginarium Net, S.L, 318 F.3d 446, 3rd Cir. (2003)

12. Kindig-It Design v. Creative Controls, No. 2:2014cv00867 - Document 124 (D. Utah. 2017)

13. Boschetto v. Hansing, No C-06-1390 VRW (N.D. Cal. Jul. 13, 2006)

14. Attaway v. Omega, 903 N.E.2d 73 (Ind.App. 2009)

15. Regulation (EU) No. 1215/2012 of the European Parliament and of the Council of 12 December 2012. Official Journal of the European Union, L $351 / 19$.

16. Lugano Convention of 16 September 1988 on the Jurisdiction and Enforcement of Judgements in Civil and Commercial Matters.

17. Regulation (EU) 2017/1001 of the European Parliament and of the Council of 14 June 2017 on the European Union trademark. Official Journal of the European Union. L 154. 16.06.2017. P. 1.

18. Case C-173/11, Football Dataco and Others v. Sportradar GmbH.

19. Case-170/12, Peter Pinckney v. KDG Mediatech AG.

20. M.N. Pankova, Substantive and legal regulation in the field of trademark protection, Bulletin of the $\mathrm{O}$. E. Kutafin University, 12(28), 106.

21. R.I. Khusainov, International jurisdiction in disputes on violation of national and unitary Trademark rights on the Internet. The experience of the European Union, Journal of the Intellectual Property Rights Court, 20, 85-93.22 (2018)

22. D.V. Krasikov, Territorial sovereignty and delimitation of jurisdictions in cyberspace, State and law in the new information reality, 1, 110 (2018)

23. H. Adams, The Education of Henry Adams, ch. 17 (1907). 